\title{
Isolated coronary artery bypass grafting in extracorporeal circulation in patients over 65 years old - does age still matter?
}

\author{
Dawid Miśkowiec ${ }^{1}$, Andrzej Walczak², Stanisław Ostrowski², Ewa Wrona ${ }^{1}$, Karol Bartczak², \\ Ryszard Jaszewski²
}

${ }^{1}$ Student VI roku Wydziału Lekarskiego Uniwersytetu Medycznego w Łodzi

${ }^{2}$ Klinika Kardiochirurgii I Katedry Kardiologii i Kardiochirurgii Uniwersytetu Medycznego w Łodzi

Kardiochirurgia i Torakochirurgia Polska 2014; 11 (2): 191-199

\begin{abstract}
Introduction: Coronary artery bypass grafting (CABG) is conducted more and more commonly in patients in advanced age. Aim of the study: To analyze the influence of age and concurrent risk factors on the complications and early mortality after CABG.

Material and methods: Medical records of 2194 patients were analyzed retrospectively. A group of 1303 patients who had undergone isolated CABG was selected. 106 (4.8\%) patients were excluded due to missing data in their medical records. The remaining 1197 patients were divided into two subgroups by age: $1^{\text {st }}$ group $<65$ years $(n=662 ; 55.3 \%) ; 2^{\text {nd }}$ group $\geq 65$ years $(n=535 ; 44.7 \%)$.

Results: The total 30-day mortality was $3.93 \%$ and was six times higher in the older group (1.21 vs. $7.29 \%$; $p<0.001)$. Complications were observed in $176(14.70 \%)$ patients, more often in the older group $(10.42 \%$ vs. $20.0 \%$; $p<0.001)$. In this group all kinds of complications were noted more often and in particular: postoperative myocardial infarction (1.96\% vs. $5.42 \%$; $p=0.001)$, respiratory dysfunction $(1.36 \%$ vs. $4.11 \% ; p=0.005)$, neurological complications ( $1.81 \%$ vs. $3.74 \% ; p=0.04)$ and multi-organ dysfunction syndrome $(0.30 \%$ vs. $1.68 \%, p=0.03)$. The older patients required longer time under mechanical ventilation ( $24.0 \pm 27.9$ vs. $37.0 \pm 74.1$ hours; $p=0.004)$ and stayed longer in the intensive care unit: $2.5 \pm 3.0$ vs. $4.1 \pm 7.84$ days; $p<0.001$. Independent predictors of death were: female sex [OR $(95 \% \mathrm{Cl})=2.4(1.2-4.5)]$, age $\geq 65$ years $[\mathrm{OR}=4.9(2.1-11.1)]$, eGFR $<60 \mathrm{~mL} / \mathrm{min} / 1.73 \mathrm{~m}^{2}$ [OR $=2.2$ (1.0-4.7)], time at extracorporeal circulation $>72$ minutes $[\mathrm{OR}=5.5(2.7-10.9)]$ and left main stem stenosis (> 50\%) [OR $=2.4(1.3-4.6)]$.

Conclusions: Age still significantly influences postoperative complications and mortality after isolated CABG. Key words: age, coronary artery bypass grafting.
\end{abstract}

\section{Streszczenie}

Wstęp: Pomostowaniu aortalno-wieńcowemu (PAW) w ostatnich latach poddawani są pacjenci w coraz bardziej zaawansowanym wieku.

Cel pracy: Ocena wpływu wieku i współistniejących czynników ryzyka na wystąpienie powikłań pooperacyjnych oraz wczesną śmiertelność pooperacyjną po izolowanym PAW.

Materiat i metody: Retrospektywnie przeanalizowano dokumentację medyczną 2194 pacjentów. Wyselekcjonowano grupę 1303 zabiegów izolowanego PAW. Z analizy wykluczono pacjentów bez kompletnego zestawu danych klinicznych $(n=106$; 4,8\%). Pozostałych 1197 pacjentów podzielono na dwie podgrupy według wieku: grupa $1-$ osoby $<65$. roku życia $(n=662$; $55,3 \%$ ); grupa 2 - osoby $\geq 65$. roku życia ( $n=535 ; 44,7 \%)$.

Wyniki: Śmiertelność 30-dniowa wyniosła 3,93\% i była ponad 6-krotnie wyższa u osób starszych (1,21 vs 7,29\%; $p<0,001)$ Powikłania wystąpiły ogółem u 176 (14,70\%) pacjentów, częściej u osób w starszej grupie wiekowej $(10,42 \%$ vs 20,0\%; $p<0,001)$. W tej grupie odnotowano również większą częstość występowania wszystkich rodzajów powikłań, w szczególności: świeżego pooperacyjnego zawału serca (1,96\% vs 5,42\%; $p=0,001)$, powikłań oddechowych $(1,36 \%$ vs $4,11 \% ; p=0,005)$ powikłań neurologicznych $(1,81 \%$ vs $3,74 \% ; p=0,04)$ oraz niewydolności wielonarządowej $(0,30 \%$ vs $1,68 \% ; p=0,03)$. Starsi pacjenci wymagali dłuższego mechanicznego wspomagania wentylacji $(24,0 \pm 27,9$ vs 37,0 $\pm 74,1$ godz.; $p=0,004)$ oraz dłużej przebywali na oddziale intensywnej opieki medycznej $(2,5$ $\pm 3,0$ vs 4,1 $\pm 7,84$ dnia; $p<0,001$ ). Niezależnymi predyktorami zgonu były: płeć żeńska [OR $(95 \% \mathrm{Cl})=2,4(1,2-4,5)]$, wiek $\geq 65$ lat $[\mathrm{OR}=4,9(2,1-11,1)]$, eGFR $<60 \mathrm{ml} / \mathrm{min} / 1,73 \mathrm{~m}^{2}[\mathrm{OR}=2,2$ $(1,0-4,7)]$, czas trwania krążenia pozaustrojowego > 72 minut $[O R=5,5(2,7-10,9)]$ oraz obecność zwężenia pnia lewej tętnicy wieńcowej (> 50\%) [OR = 2,4 (1,3-4,6)].

Wnioski: Wiek wciąż istotnie wpływa na śmiertelność i częstość występowania powikłań po izolowanym PAW.

Słowa kluczowe: wiek, pomostowanie aortalno-wieńcowe.

Address for correspondence: Dawid Miśkowiec, Department of Cardiac Surgery, Medical University of Lodz, Sterlinga 1/3, 91-425 Lodz, Poland, e-mail: dawid.miskowiec@gmail.com 


\section{Introduction}

Coronary artery bypass grafting (CABG) was performed for the first time in the 1960s. It soon became a standard approach in the treatment of ischemic heart disease (IHD), especially in patients with multivessel disease [1]. It significantly prolonged lifespan in patients above the age of 65 [2].

Recently we have been observing dynamic changes in the population of patients who have undergone cardiac surgery. Patients in advanced age with several comorbidities [3] are more and more often treated surgically, whereas until recently such patients had not been qualified for surgery due to a high risk of death. These mentioned changes were possible thanks to medical procedures which are constantly being improved and considerable development of techniques of looking after high-risk patients. The phenomenon of ageing is becoming one of the biggest challenges that medicine needs to resolve. According to the Central Statistical Office (CSO), by the year 2020, the number of people in advanced age will have risen by almost 20\%, which amounts to 2.5 million more people in this group [4]. Currently, every ninth person in the world is above the age 60. According to the United Nations (UN), this age population is going to increase by another 200 million people and will exceed 1 billion in 10 years. By 2050 the number will have doubled to 2 billion and will represent $22 \%$ of the world population (in $2006-11 \%$ ). In the light of other prognoses made by the $\mathrm{WHO}$, which predicts that by 2020 the number of deaths due to IHD will have increased to 11.1 million (an increase by $40 \%$ in comparison to 2008), the discussed problem is becoming even more serious [5].

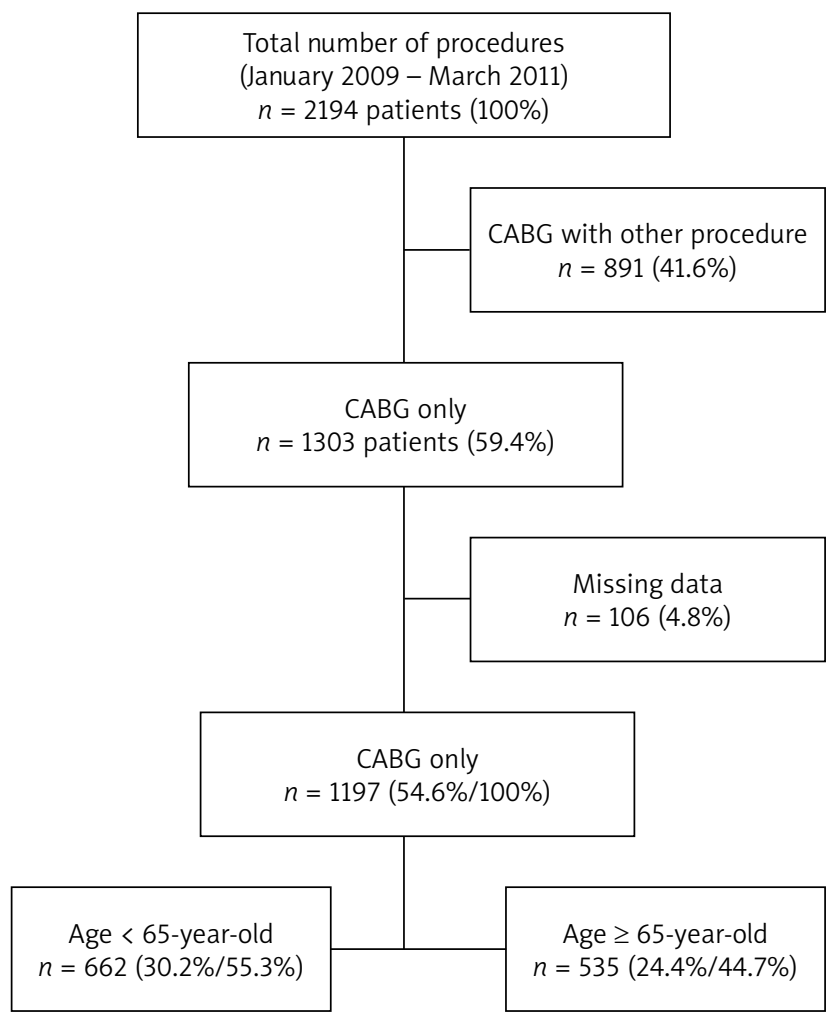

Fig. 1. Study design
Cardiac surgery is one of many disciplines that will have to face up to these dynamic changes in the population age structure.

\section{Aim of the study}

The aim of the study was to analyze the influence of age and concurrent risk factors on the type and frequency of complications as well as 30-day mortality after CABG. The authors made an attempt to identify different risk factors of death and complications and compared their distribution. The analysis was made for particular age groups.

\section{Material and methods \\ Studied group}

2194 patients operated on between 5 January 2009 and 25 March 2011 in the Department of Cardiac Surgery were analyzed retrospectively. A group of 1303 (59.4\%) patients who had undergone CABG under extracorporeal circulation (ECC) was selected. 106 (4.8\%) patients were excluded from the study due to missing data in their medical records. The remaining 1197 patients were divided into two groups. The division criteria was the age cut-off at 65 years old. The adopted age threshold was established by the WHO and implied the beginning of the advanced age populations of developed countries [6]. The first group included patients younger than 65 years $(n=662 ; 55.3 \%)$ and the other group consisted of patients aged 65 years or older ( $n$ $=535 ; 44.7 \%$ ). Figure 1 presents the study design.

\section{Surgical procedure}

Patients underwent median sternotomy. The procedure was conducted in normothermia in ECC. Cold crystalloid cardioplegia was administered after aorta cross-clamping (according to the St. Thomas' Hospital formula). In order to achieve activated clotting time (ACT) of $480 \mathrm{~s}, 300 \mathrm{lU} / \mathrm{kg}$ of heparin was administered. Its activity was neutralized by protamine sulfate in $1 \mathrm{mg}$ per $100 \mathrm{IU}$ dose of heparin at the end of the procedure.

\section{Analyzed variables}

All the conducted analyses were based on the following data set of pre- and intraoperative variables: age, gender, body mass index (BMI), body surface area (BSA), estimated glomerular filtration rate (eGFR), prior percutaneous coronary intervention $(\mathrm{PCl})$, severity of angina according to the Canadian Cardiovascular Society (CCS) Angina Grading Scale, heart failure symptoms according to the New York Heart Association (NYHA) Functional Classification, smoking, diabetes mellitus (DM), arterial hypertension (HA), hyperlipidemia, asthma, chronic obturative pulmonary disease (COPD), arrhythmias, peripheral vascular disease, cerebral vascular disease, prior cardiac surgery, left main stem (LMS) stenosis > 50\%, number of coronary arteries with stenosis $>50 \%$, number of distal coronary anastomoses, use of internal thoracic artery (ITA) as a graft, pulmonary hypertension, ejection fraction (EF), intra-aortic balloon 
pump (IABP) use, cardiogenic shock, logistic EuroSCORE, procedure duration, aortic cross-clamp time, time of ECC, time of mechanical ventilation, and time of stay in the intensive care unit (ICU).

We analyzed the occurrence of the following complications within 30-day follow-up: reoperation (reopening of the thorax or re-suturing of the sternum from any cause during the same hospitalization), postoperative myocardial infarction (elevation of cardiac biomarker values 10 times over the 99th percentile URL in patients with normal baseline cTn values; either new pathological $Q$ waves or new left bundle branch block (LBBB), or angiographic documented new graft or new native coronary artery occlusion, or imaging evidence of new loss of viable myocardium or new regional wall motion abnormality), neurological complications (stroke, depression of consciousness or confusion if associated with signs of cerebral injury on CT scan or focal neurological deficit and transient ischemic attacks with focal neurological deficit; patients with suspected neurological injury were examined by a neurologist and by CT scan; cognitive dysfunction was not assessed), respiratory complications (postoperative pneumonia defined as a positive result in a sputum culture requiring anti-infective treatment, or chest X-ray diagnosis of pneumonia and/or postoperative respiratory failure defined as the duration of mechanical ventilation more than 48 hours or re-intubation following cardiac surgery), haematological (cardiac tamponade and/ or bleeding), or multiple organ dysfunction syndrome (derangement involving two or more organ systems).

\section{Data management}

Pre-, intra- and postoperative variables were collected retrospectively thanks to the standardized form of the $\mathrm{Na}$ tional Register of Cardiac Surgery including detailed preoperative data, information about conducted procedures and postoperative period [7]. Clinical data were prospectively collected by heading surgeons, which allowed complete data records for each patient to be obtained.

\section{Statistical analysis}

In the case of categorical variables the authors gave a number of observations with feature variant (n) and the corresponding percentage (\%). In the case of continuous variables the authors gave means together with standard deviations (for normal distribution) or medians with quartiles (in the event of lack of normal distribution).

Differences between the groups for continuous variables in normal distribution were analyzed with the Student $t$-test for independent groups; other variables were analyzed with the non-parametric Mann-Whitney $U$ test. The $\chi^{2}$ and Yates' $\chi^{2}$ tests (with correction for continuity) were used for the analysis of categorical variables. Differences with $p<0.05$ were considered statistically significant.

For continuous variables with significant differences, receiver-operating characteristic (ROC) curve analysis was conducted in order to determine optimal cut-offs with the highest possible specificity and sensitivity.
The multinomial logistic regression was conducted for death as the end point. Variables with $p<0.1$ were included in further stepwise backward model analysis. Odds ratio (OR) and 95\% confidence intervals $(95 \% \mathrm{Cl})$ were computed for all end point predictors. The analyses were conducted with MedCalc version 12.2.1.0 and Statistica version 10.0.

\section{Results}

Of 2194 patients operated on in the Department of Cardiac Surgery, a group of 1303 patients (59.4\%) underwent CABG. Mean age in the analyzed population was $63.9 \pm 8.7$ years (range 34-88) and the majority were men $(n=907$; $75.77 \%)$. Moreover, younger men were also in the majority (84.0\% vs. $65.6 \%, p<0.001)$.

Diabetes mellitus was diagnosed more often in older patients $(31.9 \%$ vs. $40.6 \%, p=0.002)$, who were treated mainly with oral administration of antihyperglycemic agents $(38.0 \%$ vs. $51.2 \%, p<0.001)$.

In both the groups smokers (active and ex-smokers) made up the majority and the difference in the percentage of smokers in both the groups was statistically significant (84.9\% vs. 65.1\%, $p<0.001$ ). A higher difference was observed in active smokers in those two age groups $(19.49 \%$ vs. $3.36 \%, p<0.001)$. In younger patients concomitant hypercholesterolemia was more often observed than in older ones (92.5\% vs. $88.8 \%, p=0.03)$.

Table I presents detailed characteristics of preoperative variables between particular age groups. A significantly higher percentage of the older age group was characterized with NYHA class III or IV. The two age groups did not differ with regards to severity of angina symptoms.

Having compared the morphology of coronary arteries evaluated on the basis of data obtained from coronary catheterization, no significant difference was observed between those groups. Table II presents detailed characteristics of changes in the morphology of coronary arteries.

In the older group of patients the authors observed a significantly longer period of time under mechanical ventilation (18.6 [13.2-23.3] hours vs. 21.0 [14.3-25.3] hours, $p=0.004)$ and higher average time of stay in the ICU (2.5 \pm 3.0 days vs. $4.2 \pm 7.8$ days, $p<0.001)$. Characteristics of intraoperative and postoperative variables are presented in Table III.

Complications appeared in 176 patients (14.7\%); they were noted almost twice as often in the older age group than in the younger group (10.42\% vs. $20.0 \%$; $p<0.001)$. Also in this age group all kinds of complication were more often observed. The complications included in particular: myocardial infarction in the early postoperative period $(1.96 \%$ vs. $5.42 \%, p=0.001)$, respiratory failure (1.36\% vs. $4.11 \%, p=0.005)$, neurological complications (1.81\% vs. $3.74 \%, p=0.04)$ and multiple organ dysfunction $(0.30 \%$ vs. $1.68 \%, p=0.03)$. Frequencies of those particular kinds of complications in both the groups are presented in Table IV.

During the 30-day observation, a total of 47 patients died. Of that number 39 patients belonged to the older age 
Tab. I. Preoperative variables

\begin{tabular}{|c|c|c|c|}
\hline Preoperative variable & $\begin{array}{c}\text { Group } 1 \\
(n=662,55.3 \%)\end{array}$ & $\begin{array}{c}\text { Group } 2 \\
(n=535,44.7 \%)\end{array}$ & $p$ \\
\hline Men, $n(\%)$ & $556(83.99 \%)$ & $351(65.61 \%)$ & $<0.001$ \\
\hline BMI $\left(\mathrm{kg} / \mathrm{m}^{2}\right)$ & $28.1(25.7-30.8)$ & $27.8(25.3-30.4)$ & NS \\
\hline $\mathrm{BSA}\left(\mathrm{m}^{2}\right)$ & $1.83(1.72-1.96)$ & $1.78(1.66-1.87)$ & $<0.001$ \\
\hline EF (\%) & $52(45-60)$ & $52(55-59)$ & NS \\
\hline eGFR, median $\left(\mathrm{mL} \times \mathrm{min}^{-1} \times 1.73 \mathrm{~m}^{-2}\right)$ & $104.36(87.78-125.76)$ & $73.31(61.25-88.59)$ & $<0.001$ \\
\hline \multicolumn{4}{|l|}{ eGFR, range $\left(\mathrm{mL} \times \mathrm{min}^{-1} \times 1.73 \mathrm{~m}^{-2}\right)$} \\
\hline$>90$ & $473(75.20 \%)$ & $148(29.02 \%)$ & $<0.001$ \\
\hline $60-90$ & $138(21.94 \%)$ & $263(51.57 \%)$ & $<0.001$ \\
\hline $30-60$ & $13(2.07 \%)$ & $93(18.24 \%)$ & $<0.001$ \\
\hline$<30$ & $5(0.79 \%)$ & $6(1.18 \%)$ & NS \\
\hline Diabetes mellitus, $n$ (\%) & $211(31.87 \%)$ & $217(40.56 \%)$ & 0.002 \\
\hline Asthma, $n(\%)$ & $10(1.51 \%)$ & $11(2.06 \%)$ & NS \\
\hline COPD, $n(\%)$ & $39(3.26 \%)$ & 37 (3.09\%) & NS \\
\hline $\mathrm{HA}, n(\%)$ & $575(86.86 \%)$ & 478 (89.35\%) & NS \\
\hline Hypercholesterolemia, $n$ (\%) & $612(92.45 \%)$ & 475 (88.79\%) & 0.029 \\
\hline Smokers, $n(\%)$ & $562(84.89 \%)$ & 348 (65.05\%) & $<0.001$ \\
\hline \multicolumn{4}{|l|}{ Vascular diseases, $n$ (\%) } \\
\hline Total & $50(7.55 \%)$ & 65 (12.15\%) & 0.007 \\
\hline Peripheral & $24(3.63 \%)$ & $23(4.30 \%)$ & NS \\
\hline Cerebral & $27(4.08 \%)$ & 45 (8.41\%) & 0.002 \\
\hline \multicolumn{4}{|l|}{ Arrhythmias, $n$ (\%) } \\
\hline Total & $14(2.11 \%)$ & $31(5.79 \%)$ & $<0.001$ \\
\hline $\mathrm{AF}$ & $8(1.21 \%)$ & $16(2.99 \%)$ & 0.048 \\
\hline \multicolumn{4}{|l|}{ Previous interventions, $n$ (\%) } \\
\hline $\mathrm{PCl}$ & 200 (30.21\%) & 107 (20.00\%) & $<0.001$ \\
\hline CABG & $2(0.30 \%)$ & $1(0.19 \%)$ & NS \\
\hline
\end{tabular}

BMI - body mass index, BSA -body surface area, EF - ejection fraction, eGFR - estimated glomerular filtration rate, COPD - chronic obstructive pulmonary disease, $\mathrm{HA}$ - arterial hypertension, AF - atrial fibrillation, NS - non-significant

Tab. II. Coronary artery characteristics according to age groups

\begin{tabular}{lcccc} 
& Total & $\begin{array}{c}\text { Group 1 } \\
(n=662,55.3 \%)\end{array}$ & $\begin{array}{c}\text { Group 2 } \\
(n=535,44.7 \%)\end{array}$ & $p$ \\
Left main stem stenosis $>50 \%, n(\%)$ & $303(25.31 \%)$ & $157(23.72 \%)$ & $146(27.29 \%)$ & NS \\
\hline Single vessel disease, $n(\%)$ & $29(2.45 \%)$ & $18(2.74 \%)$ & $11(2.08 \%)$ & NS \\
\hline Double vessel disease, $n(\%)$ & $172(14.53 \%)$ & $101(15.40 \%)$ & $71(13.45 \%)$ & NS \\
\hline Triple vessel disease, $n(\%)$ & $970(81.93 \%)$ & $527(80.34 \%)$ & $443(83.90 \%)$ & NS \\
\hline
\end{tabular}

group. The total 30-day mortality was $3.93 \%$ and it was six times higher in the older age group (1.21\% vs. $7.29 \%$, $p<0.001)$. Cardiac dysfunction was the main cause of death ( $n=41 ; 87.3 \%$ of all deaths).
To identify predictors of death in the whole population, a multinomial logistic regression model with stepwise backward approach was applied. For independent continuous variables such as age, operation time, aortic cross- 
Tab. III. Intraoperative and postoperative variables

\begin{tabular}{|c|c|c|c|c|}
\hline & Total & $\begin{array}{c}\text { Group 1 } \\
(n=662,55.3 \%)\end{array}$ & $\begin{array}{c}\text { Group } 2 \\
(n=535,44.7 \%)\end{array}$ & $p$ \\
\hline ECC time, min & $71.27 \pm 26.15$ & $68.93 \pm 26.00$ & $71.32 \pm 26.14$ & 0.056 \\
\hline Aortic cross-clamp time, min & $37.55 \pm 16.91$ & $34.79 \pm 14.96$ & $37.50 \pm 16.83$ & 0.005 \\
\hline Procedure duration, min & $186.03 \pm 52.69$ & $183.46 \pm 53.18$ & $186.72 \pm 51.81$ & NS \\
\hline Elective procedure, $n(\%)$ & $1161(97.00 \%)$ & $642(96.98 \%)$ & $519(97.01 \%)$ & NS \\
\hline ITA grafting, $n(\%)$ & $1108(92.56 \%)$ & $631(95.32 \%)$ & 477 (89.16\%) & $<0.001$ \\
\hline \multicolumn{5}{|l|}{ Number of distal bypass grafts, $n(\%)$} \\
\hline 1 & $24(2.01 \%)$ & $11(1.66 \%)$ & $13(2.43 \%)$ & NS \\
\hline 2 & $293(24.48 \%)$ & $160(24.17 \%)$ & $133(24.86 \%)$ & NS \\
\hline 3 & 879 (73.43\%) & 491 (74.17\%) & 389 (72.71\%) & NS \\
\hline Mechanical ventilation time, hours & $30.14 \pm 55.13$ & $23.99 \pm 27.92$ & $37.02 \pm 74.10$ & 0.004 \\
\hline ICU stay, days & $3.23 \pm 5.75$ & $2.49 \pm 3.00$ & $4.15 \pm 7.84$ & $<0.001$ \\
\hline \multicolumn{5}{|l|}{ IABP, $n(\%)$} \\
\hline preoperative & $1(0.08 \%)$ & $1(0.15 \%)$ & $0(0.00 \%)$ & NS \\
\hline intraoperative & 19 (1.59\%) & $10(1.51 \%)$ & $9(1.68 \%)$ & NS \\
\hline postoperative & $12(1.00 \%)$ & $4(0.60 \%)$ & $8(1.50 \%)$ & NS \\
\hline
\end{tabular}

ECC - extracorporeal circulation, ITA - internal thoracic artery, ICU - intensive care unit, IABP - intra-aortic balloon pump

Tab. IV. Complication type according to age group and odds ratio (OR) with $95 \%$ confidential intervals ( $95 \% \mathrm{Cl})$ of complications in the older age patient group

\begin{tabular}{lccccc} 
Complication & Total & $\begin{array}{c}\text { Group 1 } \\
(n=662,55.3 \%)\end{array}$ & $\begin{array}{c}\text { Group 2 } \\
(n=535,44.7 \%)\end{array}$ & $p$ & OR (95\% Cl) \\
Reoperation, $n(\%)$ & $86(7.18 \%)$ & $40(6.04 \%)$ & $46(8.60 \%)$ & 0.09 & $1.46(0.94-2.27)$ \\
\hline Postoperative myocardial infarction, $n(\%)$ & $42(3.51 \%)$ & $13(1.96 \%)$ & $29(5.42 \%)$ & 0.001 & $2.86(1.47-5.56)$ \\
\hline Neurological, $n(\%)$ & $32(2.67 \%)$ & $12(1.81 \%)$ & $20(3.74 \%)$ & 0.04 & $2.10(1.02-4.34)$ \\
\hline Respiratory, $n(\%)$ & $31(2.59 \%)$ & $9(1.36 \%)$ & $22(4.11 \%)$ & 0.005 & $3.11(1.42-6.82)$ \\
\hline $\begin{array}{l}\text { Hematological (tamponade and/or } \\
\text { bleeding), } n(\%)\end{array}$ & $20(1.67 \%)$ & $7(1.06 \%)$ & $13(2.43 \%)$ & 0.10 & $2.33(0.92-5.88)$ \\
\hline Multiple organ dysfunction syndrome, $n(\%)$ & $11(0.92 \%)$ & $2(0.30 \%)$ & $9(1.68 \%)$ & 0.03 & $5.65(1.21-26.25)$ \\
\hline Infections, $n(\%)$ & $6(0.50 \%)$ & $3(0.45 \%)$ & $3(0.56 \%)$ & 0.88 & $1.24(0.25-6.16)$ \\
\hline Gastro-intestinal, $n(\%)$ & $2(0.17 \%)$ & $0(0.00 \%)$ & $2(0.37 \%)$ & 0.39 & - \\
\hline Total, $n(\%)$ & $176(14.70 \%)$ & $69(10.42 \%)$ & $107(20.00 \%)$ & $<0.001$ & $2.15(1.55-2.98)$ \\
\hline
\end{tabular}

clamp time and time of ECC, ROC curves with death as the dependent variable were applied.

ROC curves are presented in Figure 2.

A continuous variables colinearity analysis was conducted. Due to the fact that the previously mentioned variables were highly correlated with each other, the authors chose only age and time of ECC for the purpose of further analysis (lack of correlation and highest area under curve - AUC) AUC (95\% Cl) values: $A U C_{a g e}=0.722$ (0.643-0.801), $A \cup C_{\text {time of } E C C}=0.713$ (0.686-0.739).

The variable with significance value $p<0.1$ obtained in univariate analysis met inclusion criteria for the multinomial logistic regression model. Table $\mathrm{V}$ presents characteristics of patients depending on the 30-day mortality.

Independent risk factors for death were found to be: gender, age $\geq 65$ years, time of ECC longer than 72 minu- tes, LMS stenosis (> 50\%) and eGFR $<60 \mathrm{~mL} \times \mathrm{min}^{-1} \times 1.73$ $\mathrm{m}^{-2}$. Multinomial logistic regression results for death in the 30-day period after surgery are presented in Table VI.

\section{Discussion}

CABG, as the most common procedure applied in cardiac surgery, currently well illustrates the fact that the population of cardiac surgery patients is rapidly getting old. ElBardissi et al. [3] performed an analysis of the Society of Thoracic Surgeons data containing 2.5 million procedures collected from 1073 clinics around the world in 2000-2009. The gathered information shows that approximately $2 / 3$ $(60.5 \%)$ of all procedures conducted at that time were CABG. In the Department of Cardiac Surgery of the Medical University of Lodz, CABG was also the most frequent procedure (54.4\% of all procedures in the years $2009-2011)$ 


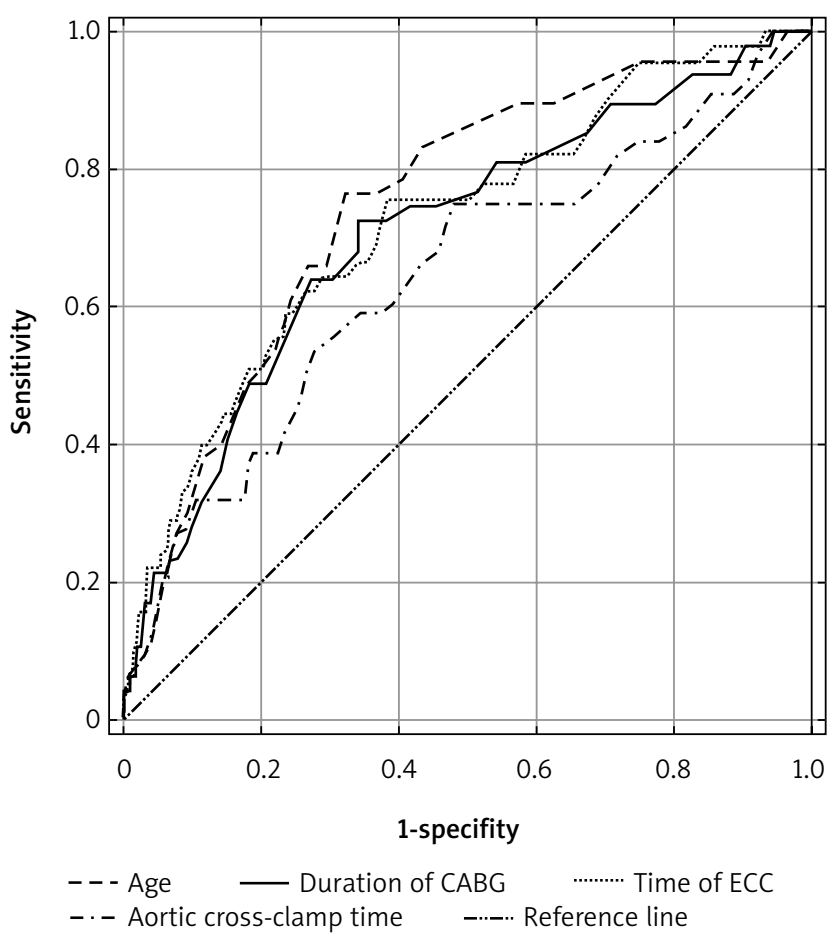

Fig. 2. ROC curves for death as a dependent variable

and on average, patients who underwent this surgery were older and older (the mean age was: 2009 - 63.4 years; 2010 -64.2 years; $2011-64.8$ years) and the trend is expected to continue in the future.

According to ElBardissi et al. the percentage of patients with $\mathrm{HA}$ has increased, in a period of ten years, from $70.9 \%$ to $85.0 \%$. A similar observation was made with regards to patients with DM (from $33.4 \%$ to $40.4 \%$ ), hyperlipidaemia (from $60.4 \%$ to $83.8 \%$ ) and COPD (from $16.9 \%$ to $22.7 \%$ ) [3]. What seems to be obvious is a direct relationship between the mentioned changes and the increasing mean age of surgical patients.

Being female is a commonly known independent risk factor $[8,9]$. After making a systematic review, Kim et al. concluded that mean age of women who underwent CABG is significantly higher than the age of men, which was also observed in our study. The percentage of women was more than twice as high as the percentage of males. Moreover, it should be emphasized that women demonstrate far more comorbidities [9], especially DM, which has a more negative influence on them rather than on men and which contributes to a worse prognosis in the female sex. Technically, CABG is more difficult to perform in women due to a smaller body size and a smaller diameter of arteries [8]. Furthermore, the use of ITA as a bypass graft [10] is less frequently performed in females. In the conducted multinomial logistic regression analysis female gender appeared to be an independent risk factor of death in the 30-day postoperative period.

In the older age group of patients the authors observed a significantly lower BSA, regardless of sex. Habib et al. reported that patients with low BSA $\left(B S A<1.7 \mathrm{~m}^{2}\right)$ require re-operations more frequently due to bleeding and numerous transfusions. Perioperative mortality in this group of patients is almost twice as high in comparison with others, which is thought to be connected with higher hemodilution volume during ECC, more frequent transfusions and more complications in this group of patients [11].

DM increases the risk of CABG [12]. As it was revealed in Zhang's meta-analysis, the relative risk (RR) of death in the group of patients with DM in contrast to the healthy group is significantly higher both in the 30 days after the procedure $(\mathrm{RR}=1.64 ; 95 \% \mathrm{Cl}=1.39-1.93)$ and in a 10-year observation period $(\mathrm{RR}=1.55 ; 95 \% \mathrm{Cl}=1.43-1.68)$ [13]. $\mathrm{DM}$ patients have more often highly advanced IHD and require multi-artery bypass grafting [12]; hence it is more difficult to provide complete full revascularization in this group of patients [14]. They are at a greater risk of stroke in the perioperative period, as well as infective complications, which are particularly hazardous in older patients [13]. In our study, there was a significantly higher percentage of DM patients in the older age group than in the younger group. The effectiveness of pharmacological control of glycemia seems to be highly visible in these patients. In the older age group monotherapy with oral antihyperglycemic agents (OAA) was more frequently administered, which could indirectly suggest a mild diabetic manifestation in these patients. According to Woods et al., patients with DM treated with OAA and who underwent CABG were less likely to have perioperative complications (neurological, renal, prolonged wound healing) than patients treated with insulin infusions [15].

According to recent guidelines, creatinine level should not be the only criterion for the assessment of kidney function. Many other factors including gender, age, BSA and muscular mass should also be considered [12]. Estimated glomerular filtration rate (eGFR) is an advisable tool to assess renal function in patients before CABG. It was confirmed that in the case of eGFR lower than $60 \mathrm{~mL} \times \mathrm{min}^{-1}$ $\times 1.73 \mathrm{~m}^{-2}$, the occurrence of severe cardiovascular events increases. In our study almost every fifth patient had eGFR $<60 \mathrm{~mL} \times \mathrm{min}^{-1} \times 1.73 \mathrm{~m}^{-2}$. According to Yeo et al., who studied 37,000 cases of CABG, consecutive stages of chronic kidney disease are characterized by a higher mortality rate in patients after elective surgery [16]. The authors found in this study that eGFR $<60 \mathrm{~mL} \times \mathrm{min}^{-1} \times 1.73 \mathrm{~m}^{-2}$ was an independent predictor of adverse outcomes, even when the age impact was adjusted and was associated with over 2-fold higher risk of death within 30 days [RR $=2.17$ (1.01-4.65)].

The almost $20 \%$ higher rate of smokers (previous or active) and more frequent hypercholesterolemia in the younger group of patients seem to be, in the opinion of the authors, the reasons for the earlier atherosclerosis onset.

COPD and asthma are commonly known risk factors of death in patients after CABG [17]. The authors observed a significantly lower percentage of concomitant COPD than was reported previously in the literature [3]. COPD was equally frequent in both age groups. Moreover, in contrast to other authors, no significant differences were observed 
Tab. V. Patients' characteristics depending on the 30-day mortality

\begin{tabular}{|c|c|c|c|}
\hline \multirow[t]{2}{*}{ Variable } & \multicolumn{3}{|c|}{ Death within 30 days after CABG } \\
\hline & $\begin{array}{c}\text { Yes } \\
(n=47,3.93 \%)\end{array}$ & $\begin{array}{c}\text { No } \\
(n=1150,96.07 \%)\end{array}$ & $p$ \\
\hline Age, years & $72(68-77)$ & $63(58-70)$ & $<0.001$ \\
\hline Men, $n(\%)$ & $25(53.19 \%)$ & $882(76.70 \%)$ & $<0.001$ \\
\hline BMI $\left(\mathrm{kg} / \mathrm{m}^{2}\right)$ & $28.02(25.28-31.07)$ & $28.03(25.40-30.61)$ & NS \\
\hline $\mathrm{BSA}\left(\mathrm{m}^{2}\right)$ & $1.76(1.66-1.89)$ & $1.88(1.74-2.01)$ & 0.001 \\
\hline EF (\%) & $52(45-58)$ & $53(45-60)$ & NS \\
\hline eGFR, median $\left(\mathrm{mL} \times \mathrm{min}^{-1} \times 1.73 \mathrm{~m}^{-2}\right)$ & $76.57(56.79-94.82)$ & $94.22(75.13-116.67)$ & $<0.001$ \\
\hline Diabetes mellitus, $n$ (\%) & $22(46.81 \%)$ & $406(35.30 \%)$ & NS \\
\hline Asthma, $n(\%)$ & $3(6.38 \%)$ & $18(1.57 \%)$ & 0.058 \\
\hline COPD, $n(\%)$ & $5(10.64 \%)$ & $71(6.17 \%)$ & NS \\
\hline HA, $n(\%)$ & $46(97.87 \%)$ & 1007 (87.57\%) & 0.057 \\
\hline Hypercholesterolemia, $n$ (\%) & $44(93.62 \%)$ & $1043(90.70 \%)$ & NS \\
\hline Smokers, $n(\%)$ & $25(53.19 \%)$ & $885(76.96 \%)$ & $<0.001$ \\
\hline Unstable angina, $n(\%)$ & $5(10.64 \%)$ & $30(2.61 \%)$ & 0.006 \\
\hline \multicolumn{4}{|l|}{ Vascular diseases } \\
\hline Total & $3(6.38 \%)$ & $112(9.74)$ & NS \\
\hline Peripheral & $0(0.00 \%)$ & $47(4.09 \%)$ & NS \\
\hline Cerebral & $3(6.38 \%)$ & $69(6.00 \%)$ & NS \\
\hline $\mathrm{AF}, n(\%)$ & $0(0.00 \%)$ & $24(2.09 \%)$ & NS \\
\hline \multicolumn{4}{|l|}{ Previous interventions } \\
\hline $\mathrm{PCl}, n(\%)$ & $10(21.28 \%)$ & $297(25.83 \%)$ & NS \\
\hline CABG, $n(\%)$ & $0(0.00 \%)$ & $3(0.26 \%)$ & NS \\
\hline Left main stenosis > 50\%, $n(\%)$ & $21(44.68 \%)$ & $282(24.52 \%)$ & 0.002 \\
\hline Triple vessel disease, $n(\%)$ & 37 (78.72\%) & $933(82.06 \%)$ & NS \\
\hline ECC time, $\min$ & $89(72-108)$ & $65(51-81)$ & $<0.001$ \\
\hline Aortic cross-clamp time, min & $43(31-61)$ & $33(24-44)$ & 0.001 \\
\hline Procedure duration, min & $215(180-255)$ & $180(150-210)$ & $<0.001$ \\
\hline EuroSCORE (logistic), \% & $4.6(2.5-6.8)$ & $3.0(1.6-5.7)$ & $<0.001$ \\
\hline Elective procedure, $n(\%)$ & $42(91.30 \%)$ & 1119 (97.39\%) & 0.05 \\
\hline ITA grafting, $n(\%)$ & $41(87.23 \%)$ & $1067(92.78 \%)$ & NS \\
\hline Mechanical ventilation time, hours & $27.13(13.3-122.75)$ & $19.00(13.67-23.67)$ & 0.024 \\
\hline ICU stay, days & $2(1-4)$ & $2(1-3)$ & NS \\
\hline IABP, $n(\%)$ & $12(25.53 \%)$ & $18(1.57 \%)$ & $<0.001$ \\
\hline Postoperative dialysis, $n$ (\%) & $4(8.51 \%)$ & $2(0.17 \%)$ & $<0.001$ \\
\hline Any complication, $n$ (\%) & $41(87.23 \%)$ & $136(11.83 \%)$ & $<0.001$ \\
\hline
\end{tabular}

BMI - body mass index, BSA - body surface area, EF - ejection fraction, eGFR - estimated glomerular filtration rate, COPD - chronic obstructive pulmonary disease, HA - arterial hypertension, AF - atrial fibrillation, ECC - extracorporeal circulation, ITA - internal thoracic artery, ICU - intensive care unit, IABP - intra-aortic balloon pump, NS - non-significant 
Tab. VI. Death predictors identified with multinomial logistic regression

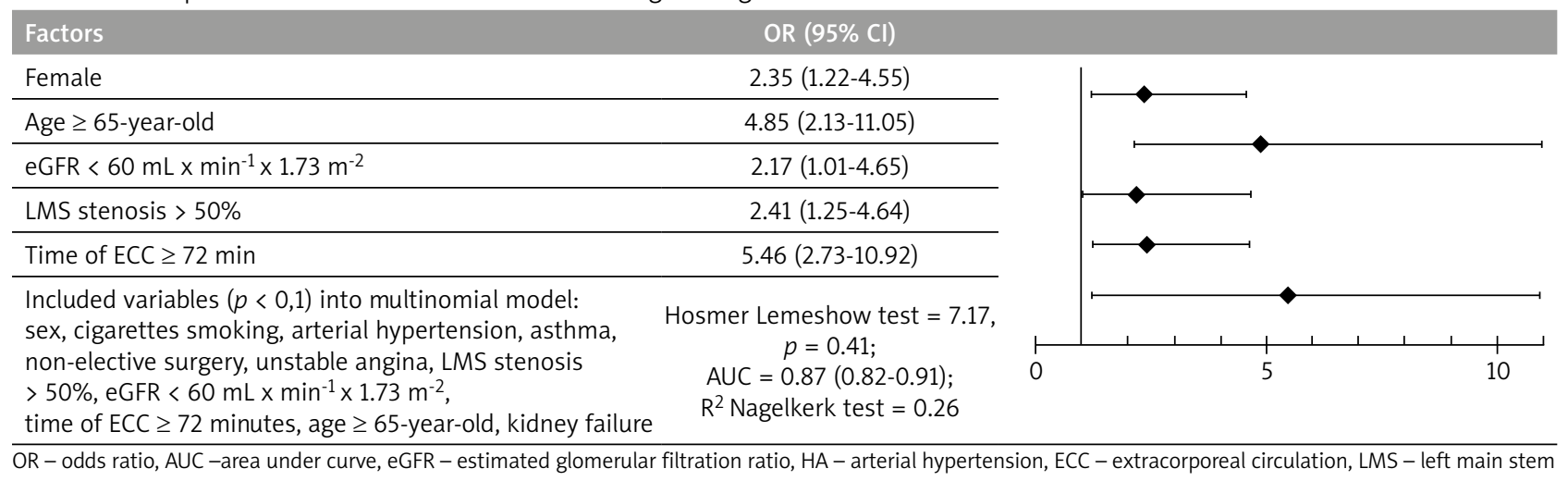

in presence of asthma between younger and older patients in our study. The lack of differences in occurrence of respiratory diseases seems to be at least partly explained by the higher rate of smokers (previous and active) among younger patients, which probably accelerated the disease onset (COPD).

Concomitant preoperative atrial fibrillation (AF) is associated with a higher risk of death and a worse long-term prognosis after CABG $[12,18]$. The risk of late mortality according to Nagaage is $40 \%$ higher in patients with preoperative AF than in those with sinus rhythm [18]. In our research any type of cardiac rhythm disturbance was observed approximately three times more frequently in the older age group, which implies a much more elevated risk in these patients.

We should point out the large number of cases where $\mathrm{PCl}$ was previously conducted, especially in the younger group of patients (30.2\%). Despite the fact that triple vessel disease and LMS changes were observed equally often, $\mathrm{PCI}$ was conducted almost in every third patient. In total, $25.6 \%$ of patients underwent $\mathrm{PCl}$ before CABG. When we compare this number with the findings of another study conducted on 34,000 patients in the United States and published in 2012 ( $\mathrm{PCl}$ rate $-22.0 \%$ in 2008), we will conclude that invasive cardiology has been intensively developing in recent years, including in Poland [19]. Although in our study the history of $\mathrm{PCl}$ was not identified as an independent risk factor, other authors have reported an adverse influence of prior $\mathrm{PCl}$ on outcomes in patients who finally underwent CABG $[19,20]$.

In comparison with the results obtained by ElBardissis et al. [3], where $8.1 \%$ of the patients had IABP performed, in our study IABP was used less frequently. These data together with a $97 \%$ rate of elective procedures imply a stable condition of patients qualified for CABG.

One of the critical conclusions of this study is a noticeably higher percentage of patients in the younger group, in whom the internal thoracic artery (ITA) was used for bypass grafting. Numerous studies have confirmed that long-term benefits of CABG can be enhanced by bypass grafting with use of arteries especially the ITA, which is particularly beneficial as it provides longer graft patency [21]. According to the recent European Society of Cardiology (ESC) guidelines on myocardial revascularization, arterial grafting to the
LAD system is highly recommended (IA) [12]. Before taking a decision on the use of the ITA the surgeons had to consider the risk in each case individually. The risk was connected with the opening of the pleural cavity. The predicted shorter life expectancy and a greater number of complications, especially in older patients, prevented surgeons from using the ITA. Rare ITA grafting in the older age group could be indirectly explained by lower BSA that correlates with lower ITA diameter and entails greater technical difficulties in CABG performance [22]. In addition, a higher percentage of women in the older age group was observed, where ITA was also used rarely [10].

Left main stem stenosis is a relatively common phenomenon that is present in up to $30 \%$ of patients currently undergoing CABG (LMS stenosis > 50\% present in this study in $25 \%$ of patients). According to the European Society of Cardiology (ESC) CABG is still regarded as the standard of care for significant LMS disease and should be performed in every case without contraindications to the surgery [12]. Nevertheless, surveys of real-word practice have reported that approximately every third patient with LMS disease is treated by $\mathrm{PCI}$ [23]. In the face of the fact that up to $80 \%$ of these patients also have multivessel coronary artery disease and simultaneous bifurcation disease [12], it is a very alarming observation. The presence of LMS stenosis has been widely considered as a strong predictor of poorer prognosis after CABG [23]. That finding is in accordance with our research results, where LMS stenosis > $50 \%$ was found to be an independent predictor of worse outcomes.

Similar analyses in patients over 65 years old who underwent CABG in our Cardiac Surgery Clinic were conducted by Walczak et al. [24] and Chiżyński et al. [25]. When we compare the mortality rate observed in this study (7.3\%) with the mortality observed in previous years by the mentioned authors, i.e. $12.7 \%$ (2002) and $8.5 \%$ (2003) respectively, we observe a systematic decrease in the oldest age group (>65) during the last decade [24, 25].

\section{Conclusions}

Patients aged 65 years or older are characterized by significantly higher mortality, are more prone to perioperative 
complications and need to stay longer in the ICU; in general, the prognosis in this group of patients is poorer.

Independent 30-day mortality predictors in patients after $C A B G$ were: being female, age $\geq 65$ years, prolonged ECC $\geq 72$ minutes, LMS stenosis and impaired renal function $\left(\mathrm{eGFR}<60 \mathrm{~mL} \times \mathrm{min}^{-1} \times 1.73 \mathrm{~m}^{-2}\right)$.

Detailed risk factor analysis is important to properly identify and select high-risk patients. It will allow prophylactic strategies to be introduced and help to avoid numerous adverse events such as death or complications.

\section{Acknowledgments}

The authors wish to thank Kinga Pietrzak for the assistance in processing the data from the National Register of Cardiac Surgery.

\section{References}

1. Serruys PW, Morice MC, Kappetein AP, Colombo A, Holmes DR, Mack MJ, Ståhle E, Feldman TE, van den Brand M, Bass EJ, Van Dyck N, Leadley K, Dawkins KD, Mohr FW; SYNTAX Investigators. Percutaneous coronary intervention versus coronary-artery bypass grafting for severe coronary artery disease. N Engl J Med 2009; 360: 961-972.

2. Weintraub WS, Grau-Sepulveda MV, Weiss JM, O'Brien SM, Peterson ED, Kolm P, Zhang Z, Klein LW, Shaw RE, McKay C, Ritzenthaler LL, Popma J), Messenger JC, Shahian DM, Grover FL, Mayer JE, Shewan CM, Garratt KN, Moussa ID, Dangas GD, Edwards FH. Comparative effectiveness of revascularization strategies. N Engl J Med 2012; 366: 1467-1476.

3. ElBardissi AW, Aranki SF, Sheng S, O'Brien SM, Greenberg CC, Gammie JS. Trends in isolated coronary artery bypass grafting: an analysis of the Society of Thoracic Surgeons adult cardiac surgery database. J Thorac Cardiovasc Surg 2012; 143: 273-281.

4. Dmochowska H, Adach-Stankiewicz E, Adamczewski W, Cierpiał-Wolan M, Jeznach M, Kamiński S, et al. Concise statistical yearbook of Poland. Statistical Publishing Establishment, Warsaw 2011.

5. Morrow DA, Gersh BJ, Braunwald E. Przewlekła choroba wieńcowa. In: Braunwald E, Zipes DP, Libby P (ed.). Choroby serca. Urban \& Partner, Wrocław 2007, p. 1251-1324.

6. Definition of an older or elderly person; http://www.who.int: World Health Organization; [cited 2013 20.02.2013]. Available from: http://www.who.int/ healthinfo/survey/ageingdefnolder/en/index.html.

7. Maruszewski B. Jakość w medycynie. Krajowy Rejestr Operacji Kardiochirurgicznych. Kardiochir Torakochir Pol 2005; 2: 86-87.

8. Kim C, Redberg RF, Pavlic T, Eagle KA. A systematic review of gender differences in mortality after coronary artery bypass graft surgery and percutaneous coronary interventions. Clin Cardiol 2007; 30: 491-495.

9. Bukkapatnam RN, Yeo KK, Li Z, Amsterdam EA. Operative mortality in women and men undergoing coronary artery bypass grafting (from the California Coronary Artery Bypass Grafting Outcomes Reporting Program). Am J Cardiol 2010; 105: 339-342.

10. Edwards ML, Albert NM, Wang C, Apperson-Hansen C. 1993-2003 gender differences in coronary artery revascularization: has anything changed? J Cardiovasc Nurs 2005; 20: 461-467.
11. Habib RH, Zacharias A, Schwann TA, Riordan CJ, Durham SJ, Shah A. Effects of obesity and small body size on operative and long-term outcomes of coronary artery bypass surgery: a propensity-matched analysis. Ann Thorac Surg 2005; 79: 1976-1986.

12. Wijns W, Kolh P, Danchin N, Di Mario C, Falk V, Folliguet T, Garg S, Huber K, James S, Knuuti J, Lopez-Sendon J, Marco J, Menicanti L, Ostojic M, Piepoli MF, Pirlet C, Pomar JL, Reifart N, Ribichini FL, Schalij MJ, Sergeant P, Serruys PW, Silber S, Sousa Uva M, Taggart D. Guidelines on myocardial revascularization. Eur Heart J 2010; 31: 2501-2555.

13. Zhang X, Wu Z, Peng X, Wu A, Yue Y, Martin J, Cheng D. Prognosis of diabetic patients undergoing coronary artery bypass surgery compared with nondiabetics: a systematic review and meta-analysis. Journal of Cardiothoracic and Vascular Anesthesia 2011; 25: 288-298.

14. Schwartz L, Bertolet M, Feit F, Fuentes F, Sako EY, Toosi MS, Davidson CJ, Ikeno F, King SB 3rd. Impact of completeness of revascularization on longterm cardiovascular outcomes in patients with type 2 diabetes mellitus: results from the Bypass Angioplasty Revascularization Investigation 2 Diabetes (BARI 2D). Circ Cardiovasc Interv 2012; 5: 166-173.

15. Woods SE, Eppley C, Engel A. The influence of diabetes mellitus in patients undergoing coronary artery bypass graft surgery: a prospective cohort study. Am Surg 2008; 74: 839-844.

16. Yeo KK, Li Z, Yeun JY, Amsterdam E. Severity of chronic kidney disease as a risk factor for operative mortality in nonemergent patients in the California coronary artery bypass graft surgery outcomes reporting program. Am J Cardiol 2008; 101: 1269-1274.

17. Saleh HZ, Mohan K, Shaw M, Al-Rawi O, Elsayed H, Walshaw M, et al. Impact of chronic obstructive pulmonary disease severity on surgical outcomes in patients undergoing non-emergent coronary artery bypass grafting. European journal of cardio-thoracic surgery : official journal of the European Association for Cardio-thoracic Surgery 2012; 42: 108-113; discussion 13.

18. Ngaage DL, Schaff HV, Mullany CJ, Sundt TM, 3rd, Dearani JA, Barnes S, Daly RC, Orszulak TA. Does preoperative atrial fibrillation influence early and late outcomes of coronary artery bypass grafting? J Thorac Cardiovasc Surg 2007; 133: 182-189.

19. Mehta GS, LaPar DJ, Bhamidipati CM, Kern JA, Kron IL, Upchurch GR, Jr., Ailawadi G. Previous percutaneous coronary intervention increases morbidity after coronary artery bypass grafting. Surgery 2012; 152: 5-11.

20. Chocron S, Baillot R, Rouleau JL, Warnica WJ, Block P, Johnstone D, Myers MG, Calciu CD, Nozza A, Martineau P, van Gilst WH; IMAGINE Investigators. Impact of previous percutaneous transluminal coronary angioplasty and/ or stenting revascularization on outcomes after surgical revascularization: insights from the imagine study. Eur Heart J 2008; 29: 673-679.

21. Sabik JF, 3rd, Blackstone EH, Gillinov AM, Banbury MK, Smedira NG, Lytle BW. Influence of patient characteristics and arterial grafts on freedom from coronary reoperation. J Thorac Cardiovasc Surg 2006; 131: 90-98.

22. Woods SE, Noble G, Smith JM, Hasselfeld K. The influence of gender in patients undergoing coronary artery bypass graft surgery: an eight-year prospective hospitalized cohort study. J Am Coll Surg 2003; 196: 428-434.

23. Ngaage DL, Sogliani F, Augustine T. Early and late survival after surgical revascularisation for left main coronary artery stenosis in stent era. $\mathrm{Br}$ J Cardiol 2012; 19: 134-138.

24. Walczak A, Jaszewski R, Jegier B, Iwaszkiewicz A, Ostrowski S, Zwoliński R, et al. Early results of surgical coronary revascularization in patients 65 years and older. Przegląd Lekarski 2002; 59: 239-240.

25. Chizynski K, Jaszewski R, Iwaszkiewicz-Zaslonka A, Zaslonka J. Coronary surgery in patients over 65 year of age. Przegląd Lekarski 2003; 60: 495-498. 